\title{
Paranasal Manifestations of Early Stage Chronic Lymphocytic Leukemia
}

\section{Erken Evre Kronik Lenfositik Löseminin Paranazal Belirtileri}

\author{
Ceren Günel', Irfan Yavaşoğlu², İbrahim Meteoğlư , Ali Toka', Nihan Alkış \\ 'Adnan Menderes Üniversitesi Tip Fakültesi, Kulak Burun Boğaz Baş Boyun Cerrahisi Anabilim Dalı, Aydın, Türkiye \\ ²Adnan Menderes Üniversitesi Tıp Fakültesi, İ Hastallkları Anabilim Dalı, Aydın, Türkiye \\ ${ }^{3}$ Adnan Menderes Üniversitesi Tip Fakültesi, Tibbi Patoloji Anabilim Dalı, Aydın, Türkiye
}

\begin{abstract}
OBJECTIVE: Chronic lymphocytic leukemia (CLL) is the most common adult leukemia. A few studies have been reported about the relationship between CLL and paranasal sinuses. We aimed to investigate the paranasal manifestations of $\mathrm{CLL}$ and to determine the expression of nuclear factor-kB (NF-kB) and tumor necrosis factor (TNF-a) in the nasal mucosa in patients with CLL.
\end{abstract}

MATERIALS AND METHODS: This study was a clinical trial that involved 40 patients. Group CLL $(n=20)$ consisted of patients with early-stage CLL who were followed-up at the hematology clinic and who did not receive any treatment. The control group $(n=20)$ consisted of patients who had undergone concha surgery because of nasal obstruction. Paranasal sinus computer tomography scans of all patients were taken, they were scored on the basis of the Lund-Mackay system, and sinusitis findings were recorded. The biopsy material taken from the inferior concha head of all patients was immunohistochemically stained with primary antibodies against NF-kB and TNF- $a$.

RESULTS: There were no statistically significant differences between the two groups with respect to NF-KB ( $p=0.716)$ and TNF- $a$ staining scores $(p=1.000)$. The Lund-Mackay scores were significantly higher in the CLL group than in the control group $(p=0.004)$. Fourteen patients had sinusitis at different locations, while the most common diagnosis was maxillary sinusitis $(n=8)$ in the $C L L$ group. CONCLUSION: This study showed that patients with early-stage CLL tend to have rhinosinusitis. However, NF-kB and TNF-a may not have a role in the inflammatory process involving the paranasal sinuses in patients with CLL.

KEYWORDS: Chronic lymphocytic leukemia, NF-Kb, TNF- $a$, Lund-Mackay score, rhinosinusitis
Özet

AMAÇ: Kronik lenfositik lösemi (KLL) en yaygın görülen yetişkin lösemi alt grubudur. Ancak paranazal sinüsler ve KLL arasındaki ilişkiyi araştıran az sayıda çalışma rapor edilmiştir. Bu çalışmada KLL'nin paranazal belirtilerini ve KLL hastalarının nazal mukozalarında Nuclear factor-KB (NF-kB) ve Tumor necrosis factor (TNF-a) salınımını saptamayı amaçlandı.

GEREÇ VE YÖNTEMLER: Bu çalışma 40 hastayı içeren bir klinik çalışma olarak yapılmıştır. Grup KLL $(n=20)$ herhangi bir tedavi almamış hematoloji kliniği tarafından takip edilen erken evre KLL hastalarından oluşturuldu. Kontrol grubu $(n=20)$ burun tıkanıklığı nedeniyle konka cerrahisi geçirmiş hastalardan oluşturuldu. Tüm hastaların paranazal sinus tomografileri çekilip Lund Mackay sistemine gore skorlandı ve sinüzit bulguları kaydedildi. Tüm hastaların alt konka başından alınan biyopsi materyalleri, NF-kB and TNF-a primer antikorları ile immünohistokimyasal olarak boyandı.

BULGULAR: İki grup arasında NF-KB $(p=0.716)$ ve TNF- $a(p=1.000)$ boyama skorlarına göre istatistiksel olarak anlamlı farklılık yoktu. Lund-Mackay skoru $(p=0.004)$ kontrol grubuna göre KLLgrubunda anlamlı olarak daha yüksek bulundu. KLL grubunda en yaygın tanı maksiler sinüzit $(n=8)$ iken, 14 hastada farklı lokalizasyonlarda sinüzit bulguları saptandı.

SONUÇ: Bu çalışma erken evre KLL hastalarının akut rinosinüzite eğilimli olduğunu göstermektedir. Bununla birlikte, paranazal sinüsleri kapsayan inflamatuvar süreçte NF-kB ve TNF- $a$ bir role sahip olmadığını düşünmekteyiz.

ANAHTAR KELIMELER: Kronik lenfositik lösemi, NF-kB, TNF-a, Lund-Mackay skor, rinosinüzit

\section{Introduction}

Chronic lymphocytic leukemia (CLL) is the most frequent leukemia of adults and is considered a malignancy of B lymphocyte (1). Although spleen and lymph nodes are usually involved, head and neck region involvement is uncommon (2). Immunosuppression is commonly associated with CLL, and $25 \%-50 \%$ of patients with CLL die of respiratory or urinary tract infections (3).

It is known that nuclear factor-kB (NF-kB) transcription factor contributes to apoptosis and survival success of the cell by regulating the expression of more than 150 genes, including those encoding several cytokines, cell surface receptors, and molecules involved in

Correspondence to / Yazışma adresi: Ceren Günel, Adnan Menderes Üniversitesi Tıp Fakültesi, Kulak Burun Boğaz Baş Boyun Cerrahisi Anabilim Dalı, Aydın, Türkiye Phone / Tel.: +905337175693 e.mail / e.posta: drgunel@hotmail.com Received / Geliş Tarihi: 01.04.2015 • Accepted / Kabul Tarihi: 21.04.2015 
cell growth and differentiation, lymphocyte activation, and inflammation (4). In many solid tumors and hematological malignancies, including CLL, NF-KB dimers are constitutively active. This constitutive activation of NF-KB causes not only malignant transformation and tumor progression but also enables the tumor cells to evade immune surveillance (5). In CLL, NF-KB has been found to be activated in the tissues to a variable degree, regardless of the disease stage or treatment status. Its activity seems to sustain tumor cell survival and enhance cell sensitivity to some inhibitor. In addition, NF-KB activation may suppress apoptosis in CLL cell lines (6).

Tumor necrosis factor (TNF-a) plays a role in the inflammation and immune response by inducing the inflammatory cytokines (7). Besides, TNF-a significantly increases nuclear translocation of NF-Kb $(8,9)$. Elevated levels of TNF have been observed in patients with CLL, and an association with disease progression has been found (10).

Some inflammatory stimuli elicit biological responses through the activation of NF-KB and TNF-a signal cascades in inflammatory airway diseases such as rhinosinusitis and allergic rhinitis $(10,11)$.

A few studies have been reported about the relationship between CLL and paranasal sinuses $(2,12-14)$. We aimed to investigate the nasal manifestations of CLL and to determine the expression of NF-KB and TNF- $a$ in the nasal mucosa in patients with CLL.

\section{Materials and Methods}

The study was approved by the ethics committee of the university hospital. This retrospective study was conducted between January 1, 2014, and October 1, 2014. A total of 40 patients were enrolled in the study. The patients were assigned to two groups: Group CLL and control group. Patients with CLL who were referred to our otolaryngology outpatient clinic from a hematology clinic with upper respiratory tract infection and/or suspected leukemia involvement were identified. Patients who had undergone paranasal sinus computed tomography were included in this study. Group CLL $(n=20)$ consisted of patients with early-stage CLL (binet A) who were followed-up at the hematology clinic and who did not receive any treatment. The control group $(n=20)$ consisted of patients who had undergone concha surgery because of nasal obstruction. Patients with a known non-CLL malignancy and abnormal bleeding profile in the CLL group and patients who had previously undergone endoscopic sinus surgery, recently received chronic rhinosinusitis (CRS) treatment, had one-sided nasal mass, and nasal polyposis in the control group were excluded from the study. Paranasal sinus computed tomography (PNS CT) scans of both groups were taken and scored on the basis of the grading system developed by Lund-Mackay (15). The sinusitis findings determined from PNS CT were recorded. The evaluations were made by a single physician (C.G).

Pathology slides consisting of the biopsy material taken from the inferior concha of all patients were evaluated. Then, the slides were subjected to immunohistochemical staining. Immunohistochemical staining was performed using DAKO Autostainer Universal Staining System (Autostainer Link 48 DAKO, Glostrup, Denmark). First, 4- $\mu \mathrm{m}$ sections were mounted on positive loaded glass slides. Then, the sections were deparaffinized with xylol and dehydrated by passing through ethyl alcohol series. Then, antigen retrieval was made in a thermostatic bath (PT Link) at $96^{\circ} \mathrm{C}(10 \mathrm{mM} / \mathrm{L}$ citrate buffer, $\mathrm{pH}$ 6) for
$40 \mathrm{~min}$. The sections were incubated for $60 \mathrm{~min}$ with primary antibodies against NF-KB/p50 (RB-1648; NeoMarkers, Fremont, CA, USA) and TNF-a (LS-B2123, LifeSpan, BioSciences, WA, USA). Using the streptavidin-biotin immunoperoxidase technique (K8000 Envision Flex, DAKO, Glostrup, Denmark), an automatized system was used. In order to ensure the color image, immunoreactions with diaminobenzidine tetrachloride (DAB) were displayed. For background staining, the sections were oppositely stained with hematoxylin. For dehydration, the sections were passed through alcohol series with increasing strength and after clearing in xylol, they were lined with balsam. After staining, the sections were examined under light microscope (Olympus BX51, Tokyo, Japan) at 4x, 10x, 20x, and 40x magnifications by a single pathologist blind to the patient's history and CT findings. In the highly stained areas (hot spots), minimum 200 cells were counted. They were scored as follows: staining <5\%: $0 ; 5 \%-10 \%$ : $1 ; 11 \%-20 \%: 2$; >20\%: 3.

SPSS 19 (SPSS Yazılım eğitim danışmanlık şirketi, Istanbul, Turkey) was used for calculations and statistical analysis. The Mann-Whitney $\mathrm{U}$ test was used to compare the Lund-Mackay scores. To analyze the categorical variables, a Chi-square test was used. Descriptive statistics are presented as mean \pm standard deviation, median (25-75 percentile), and frequency (percentage). p values below 0.05 were considered statistically significant.

\section{Results}

Forty patients were included in this study. Twenty (50\%) patients were female. The mean ages of the CLL and control group were $68.90 \pm 6.711$ years and $34.25 \pm 6.882$ years, respectively. The baseline characteristics of the CLL group are presented in Table 1. There were no statistically significant differences between the two groups with respect to NF-KB $(p=0.716)$ and TNF- $a(p=1.000)$ staining scores (Table 2). The median Lund-Mackay score in the CLL group was 1 $(1-2)$, while in control group, it was $0(0-1)$. The Lund-Mackay score were significantly higher in the CLL group than in the control group $(p=0.004)$. Fourteen patients had sinusitis at the different locations, while the most common diagnosis was maxillary sinusitis $(n=8)$ in the CLL group (Table 3). In the control group, 6 patients had localized sinusitis. This difference was statistically significant $(p=0.27)$.

\section{Discussion}

Chronic lymphocytic leukemia is the most common adult leukemia. Majority of the cases involve asymptomatic patients diagnosed at routine blood examination (16). Some of the patients apply to the hospital with enlargement of splenic and lymphatic nodes, anorexia, and weight loss. If the patients are asymptomatic, they may not

Table 1. Baseline characteristics of the CLL group

\begin{tabular}{lc}
\hline Blood profile & Mean \pm sd \\
\hline Hemoglobin & $11,860 \pm 3,927$ \\
Hematocrit & $36,335 \pm 11,953$ \\
Leukocyte & $44,779 \pm 34,096$ \\
Neutrophil & $6096,500 \pm 2900,165$ \\
Lymphocyte & $37,136 \pm 32,924$ \\
Platelets & $237,000 \pm 88,321$ \\
\hline
\end{tabular}


Table 2. NF-KB and TNF-a staining scores of the groups

\begin{tabular}{|c|c|c|c|c|c|c|}
\hline \multirow[b]{2}{*}{ Staining scores } & \multicolumn{2}{|c|}{ NF-кB } & \multirow[t]{2}{*}{$p$ value } & \multicolumn{2}{|c|}{ TNF- $a$} & \multirow[t]{2}{*}{ p value } \\
\hline & 0 & 1 & & 0 & 1 & \\
\hline $\begin{array}{l}\text { CLL group } \\
n(\%)\end{array}$ & $4(20 \%)$ & $16(80 \%)$ & 0.716 & $17(85 \%)$ & $3(15 \%)$ & 1.000 \\
\hline $\begin{array}{l}\text { Control group } \\
\mathrm{n}(\%)\end{array}$ & $6(30 \%)$ & $14(70 \%)$ & & $18(90 \%)$ & $2(10 \%)$ & \\
\hline
\end{tabular}

TNF-a: Tumor necrosis factor, NF-kB: Nuclear factor-kB.

0 : staining $<5 \%$, 1 : staining between $5 \%-10 \%$.

Table 3. Diagnoses and Lund-Mackay scores of CLL patients

\begin{tabular}{|c|c|c|}
\hline Patients & Lund-Mackay Score & Diagnoses \\
\hline 1 & 2 & Maxillary sinusitis \\
\hline 2 & 2 & Maxillary sinusitis \\
\hline 3 & 1 & Maxillary sinusitis \\
\hline 4 & 2 & Maxillary sinusitis \\
\hline 5 & 0 & - \\
\hline 6 & 2 & Maxillary sinusitis \\
\hline 7 & 1 & Maxillary sinus retention cyst \\
\hline 8 & 2 & Maxillary sinusitis \\
\hline 9 & 1 & Osteoma in ethmoid sinus \\
\hline 10 & 4 & Ethmoidal sinusitis \\
\hline 11 & 1 & Sphenoidal sinusitis \\
\hline 12 & 1 & Ethmoidal sinusitis \\
\hline 13 & 3 & Maxillary sinusitis \\
\hline 14 & 0 & - \\
\hline 15 & 1 & Ethmoidal sinusitis \\
\hline 16 & 6 & Maxillary and ethmoidal sinusitis \\
\hline 17 & 1 & Maxillary sinus retention cyst \\
\hline 18 & 1 & Ethmoidal sinusitis \\
\hline 19 & 1 & Maxillary sinus retention cyst \\
\hline 20 & 1 & Sphenoidal sinusitis \\
\hline
\end{tabular}

be treated (16). In our study, the CLL group consisted of early-stage untreated patients. The baseline properties of the patients are given in Table 1.

Chronic lymphocytic leukemia involvement of paranasal sinuses is extremely rare. A few studies have been reported in the literature. In two of them, leukemic infiltration of the nasolacrimal duct was identified. In one of the studies, sinusitis findings were also present $(13,14)$. Johnston et al. have determined leukemic infiltration in the histopathological examination of patients operated for chronic pansinusitis (2). The common characteristic of these patients is the sinusitis symptoms arising out of obstruction secondary to mucosal leukemic infiltration. In our study, nasal leukemic infiltration was not determined in any patient. Although rarely encountered, otolaryn-

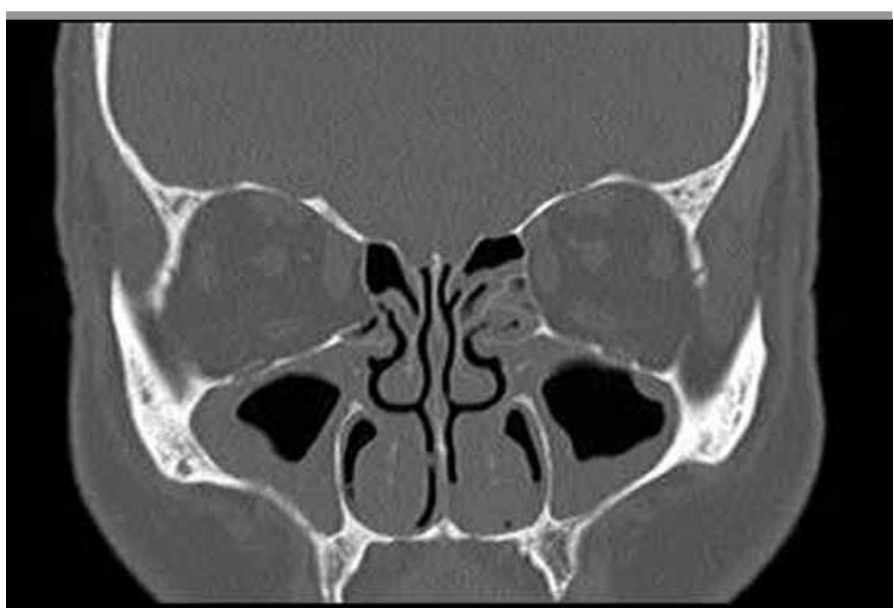

Figure 1. Maxillary and ethmoidal sinusitis are seen in the coronal section of paranasal CT

gologists should be vigilant for mucosal leukemic infiltration, especially in patients with CRS findings.

The relationship between CLL and paranasal sinuses is not clearly identified in the literature, and $25 \%--50 \%$ of CLL patients lose their lives because of infections. Some of these infections are respiratory tract infections. In these patients, there may be different low percentages of $\lg G, \lg A$, and $\lg M$, and they may be prone to infections because of hypogammaglobulinanemia (17). The partial disruption of mucosal immunity also makes these patients prone to respiratory tract infections. It is not surprising to anticipate an increase in infections, especially during the chemotherapy treatment. Furthermore, in advanced-stage CLL patients, fungal and viral infection incidences increase (2).

Although in our study, the CLL group consisted of early-stage untreated patients, the incidence of rhinosinusitis was significantly higher than that in the control group. However, sinusitis findings were local. Although mostly maxillary sinusitis were observed in paranasal sinus computed tomography $(n=7)$, isolated ethmoidal findings were identified in 4 patients, isolated sphenoid sinusitis in 2 patients, and ethmoidal and maxillary sinusitis together in 1 patient (Figure 1). These findings prove that CLL patients, even at the early stage, are prone to upper respiratory tract infections. CLL patients with a weak immune system appear to have a high risk potential for upper respiratory tract infections and the complications likely to follow.

Recent studies have found out that NF-KB exists in almost all types of cells and is in the inactive form depending on the specific inhibitors in the cytoplasm. Extracellular stimulants, including bacteria, viruses, growth factors, chemotherapeutic agents, ionizing radiation, oncogenes, carcinogens, interleukins, lipopolysaccharides, immunoglobulins, reactive oxygen species, and various psychological, physiological, and oxidative stress stimulants, activate NF-кB molecules. Activated NF-KB controls the gene expression related to cell growth, differentiation, cytokine production, hematopoiesis, transformation, apoptosis, proliferation, immunity, invasion, angiogenesis, and metastasis. The nuclear translocation and activation of NF-KB plays a key role in the inflammatory response, particularly because it induces the transcription of proinflammatory genes (18-20). 
TNF plays a key role in local inflammatory and immune response by inducing the expression of inflammatory cytokines (7). Epithelial damage, desensitization of odorant-induced signaling, and apoptotic loss of olfactory neurons are mainly associated with increased TNF-a production in the subepithelial layer of CRS. TNF- $a$ can also have adverse effects on the respiratory mucosa, causing ciliated cell loss, epithelial metaplasia, and further accumulation of inflammatory cells in the subepithelial layer (21). In recent studies, it has been demonstrated that NF-kB and TNF-a ratios that have a role in the inflammatory pathway increase in patients with CRS $(21,22)$. In addition, the function of $T$ regulatory cells could be correlated with levels of TNF-a, and TNF-a may increase in patients with CLL (23). In our study, we aimed at assessing the paranasal sinuses in patients with CLL. For this purpose, we compared NF-kB and TNF-a expression in the concha mucosa of CLL patients, which play a role in the inflammatory response, with the control group. However, we did not find any significant difference between the two groups with respect to these two mediators. This finding may demonstrate that the paranasal sinus mucosa of early-stage CLL patients is not different from that of healthy individuals and there is no inflammatory process.

\section{Conclusion}

As a result, early-stage CLL patients tend to have paranasal sinus infections. This study suggests that it is important for these patients to be followed-up by an otolaryngologist for rhinosinusitis and associated complications. However, in the nasal mucosa of these patients, no increase in NF-kB and TNF-a expression, which have a role in the inflammatory pathway, was determined. Therefore, in early-stage CLL patients, a NF-kB- and TNF-a-mediated inflammatory process involving the paranasal sinuses may not be unexpected.

Ethics Committee Approval: Ethics committee approval was received for this study from the Ethics Committee of Faculty of Medicine (2014/283).

Informed Consent: Written informed consent was obtained from relatives of the patient who participated in this study.

Peer-review: Externally peer-reviewed.

Author Contributions: Concept - C.G., I.Y.; Design - I.Y.; Supervision - I.Y.; Funding - I.M.; Data Collection and/or Processing - I.M., A.T., N.A.; Literature Review - A.T.; Writing - C.G.; Critical Review - I.M.; Other - I.M., C.G., I.Y.

Conflict of Interest: No conflict of interest was declared by the authors.

Financial Disclosure: The authors declared that this study has received no financial support.

Etik Komite Onayı: Bu çalışma için etik komite onayı alınmıştır.

Hasta Onamı: Yazılı hasta onamı bu çalışmaya katılan hastadan alınmıştır.

Hakem değerlendirmesi: Dış bağımsız.

Yazar Katkıları: Fikir - C.G., I.Y.; Tasarım - I.Y.; Denetleme - I.Y.; Kaynaklar - I.M.; Veri toplanması ve/veya işlemesi - I.M., A.T., N.A; Literatur taraması - A.T.; Yazıyı yazan - C.G.; Eleştirel İnceleme - I.M.; Diğer - I.M., C.G., I.Y.

Çıkar Çatışması: Yazarlar çıkar çatışması bildirmemişlerdir.

Finansal Destek: Yazarlar bu çalışma için finansal destek almadıklarını beyan etmişlerdir.

\section{References}

1. Furman RR, Asgary Z, Mascarenhas JO, Liou HC, Schattner EJ. Modulation of NF-kappa B activity and apoptosis in chronic lymphocytic leukemia B cells. J Immunol 2000; 164: 2200-06. [CrossRef]
2. Johnston R, Altman KW, Gartenhaus RB. Chronic lymphocytic leukemia manifesting in the paranasal sinuses. Otolaryngol Head Neck Surg 2002; 127: 582-4. [CrossRef]

3. Pagedar NA, Halfdanarson TR, Karnell LH, Hoffman HT, Funk GF. Upper aerodigestive tract cancer in patients with chronic lymphocytic leukemia: incidence, stage, and outcome. Arch Otolaryngol Head Neck Surg 2012; 138: 1171-5. [CrossRef]

4. Richmond A. Nf-kappa B, chemokine gene transcription and tumour growth. Nat Rev Immunol 2002; 2: 664-74. [CrossRef]

5. Turco MC, Romano MF, Petrella A, Bisogni R, Tassone P, Venuta S. NF-KB/ Rel-mediated regulation of apoptosis in hematologic malignancies and normal hematopoietic progenitors. Leukemia 2004;18:11-7. [CrossRef]

6. Gasparini C, Celeghini C, Monasta L, Zauli G. NF-KB pathways in hematological malignancies. Cell Mol Life Sci 2014;71:2083-02. [CrossRef]

7. Batikhan H, Gokcan MK, Beder E, Akar N, Ozturk A, Gerceker M. Association of the tumor necrosis factor-alpha $-308 \mathrm{G} / \mathrm{A}$ polymorphism with nasal polyposis. Eur Arch Otorhinolaryngol 2010;267:903-8. [CrossRef]

8. Ohori J, Ushikai M, Sun D, et al. TNF-alpha upregulates VCAM-1 and NF-kappaB in fibroblasts from nasal polyps. Auris Nasus Larynx 2007; 34: 177-83. [CrossRef]

9. Wang Z, Zhang Q, Li Y, Li P, Zhang G, Li Y. Involvement of mitogen-activated protein kinases and nuclear factor kappa $B$ pathways in signaling COX-2 expression in chronic rhinosinusitis. Inflamm Res 2009; 58: 649-58. [CrossRef]

10. Valencia X, Stephens G, Goldbach-Mansky R, Wilson M, Shevach EM, Lipsky PE. TNF downmodulates the function of human CD4+CD25hi T-regulatory cells. Blood 2006; 108: 253-61. [CrossRef]

11. Wang SZ, Ma FM, Zhao JD. Expressions of nuclear factor-kappa B p50 and p65 and their significance in the up-regulation of intercellular cell adhesion molecule-1 mRNA in the nasal mucosa of allergic rhinitis patients. Eur Arch Otorhinolaryngol 2013; 270: 1329-34. [CrossRef]

12. Pagedar NA, Halfdanarson TR, Karnell LH, Hoffman HT, Funk GF. Upper aerodigestive tract cancer in patients with chronic lymphocytic leukemia: incidence, stage, and outcome. Arch Otolaryngol Head Neck Surg 2012; 138: 1171-5. [CrossRef]

13. Wong RJ, Gliklich RE, Rubin PA, Goodman M. Bilateral nasolacrimal duct obstruction managed with endoscopic techniques. Arch Otolaryng Head Neck Surg 1998; 124: 703-6. [CrossRef]

14. Munro S, Brownstein S, Jordan DR, Mcleish W. Nasolacrimal obstruction in two patients with chronic lymphocytic leukemia.Can J Opthalmol 1994; 29: 137-40

15. Lund VJ, Mackay IS. Staging in rhinosinusitis. Rhinology 1993; 31: 183-4.

16. Rozman C, Montserrat E. Chronic lymphocytic leukemia. N Engl J Med 1995; 333: 1052-7. [CrossRef]

17. Morrison VA. The infectious complications of chronic lymphocytic leukemia. Semin Oncol 1998; 25: 98-106.

18. Baldwin AS Jr. The NF-kappa B and I kappa B proteins: new discoveries and insights. Annu Rev Immunol 1996; 14: 649-83. [CrossRef]

19. Li $Q$, Verma IM. NF-kB regulation in the immun system. Nat Rev Immunol 2002; 2: 725-34. [CrossRef]

20. Gasparini C, Celeghini C, Monasta L, Zauli G. NF-KB pathways in hematological malignancies. Cell Mol Life Sci 2014; 71: 2083-102. [CrossRef]

21. Karosi T, Csomor P, Sziklai I. Tumor necrosis factor-a receptor expression correlates with mucosal changes and biofilm presence in chronic rhinosinusitis with nasal polyposis. Laryngoscope 2012; 122: 504-10. [CrossRef]

22. Valera FC, Umezawa $K$, Brassesco MS, et al. Suppression of inflammatory cytokine secretion by an NF-KB inhibitor DHMEQ in nasal polyps fibroblasts. Cell Physiol Biochem 2012; 30: 13-22. [CrossRef]

23. Ferrajoli A, Keating MJ, Manshouri T, et al. The clinical significance of tumor necrosis factor-alpha plasma level in patients having chronic lymphocytic leukemia. Blood 2002; 100: 1215-9. 